九州大学学術情報リポジトリ

Kyushu University Institutional Repository

\title{
Analysis of Modified Solar Water Heating System Made of Transparent Tubes \& Insulated Metal Absorber
}

Tewari, Kirti

Department of Mechanical Engineering, Motilal Nehru National Institute of Technology Allahabad

Dev, Rahul

Department of Mechanical Engineering, Motilal Nehru National Institute of Technology Allahabad

https://doi.org/10.5109/1929731

出版情報：Evergreen. 5（1），pp.62-72，2018-03. 九州大学グリーンアジア国際リーダー教育センター バージョン：

権利関係 : 


\title{
Analysis of Modified Solar Water Heating System Made of Transparent Tubes \& Insulated Metal Absorber
}

\author{
Kirti Tewari ${ }^{1, *}$, Rahul Dev ${ }^{1}$ \\ ${ }^{1}$ Department of Mechanical Engineering, Motilal Nehru National Institute of Technology Allahabad, \\ Allahabad-211004, U.P, India \\ *Author to whom correspondence should be addressed, \\ E-mail: ktkirtitewari@gmail.com
}

(Received January 6, 2018; accepted March 12, 2018).

\begin{abstract}
Modified solar water heating system (MSWHS) of 200L is a modification over the existing technologies of flat plate collector and evacuated tubular collector. In the present communication, MSWHS has been modeled using MATLAB R2014a and evaluated for the climatic data of Allahabad, India for the year 2015-16. The maximum temperature of water in the storage tank and tubes of collector have been found to be $85{ }^{\circ} \mathrm{C}$ and $89{ }^{\circ} \mathrm{C}$ in the month of May respectively. The parametric study has also been carried out. Further, the study has also been extended for life cycle assessment and cost analysis of the setup. The embodied energy of the setup is found to be $1658.73 \mathrm{kWh}$.
\end{abstract}

Keywords: Flat plat collector (FPC), Evacuated tube collector (ETC), methyl methacrylate (Acrylic), Fiber reinforced plastic (FRP).

\section{Introduction}

In today's scenario requirement of hot water is increasing at industrial as well as domestic level. So nowadays, solar water heaters are being used to utilize renewable sources of energy. The solar water heater uses thermal energy of incident solar radiation to heat water. These are either natural flow (works on thermosiphon effect) or forced flow type (make use of pumps). These are also classified as FPC and ETC, at higher temperature ETC are efficient while at lower temperature FPC are used. In recent years, the efficiency of solar water heaters has been improved by increasing the area of heat transfer ${ }^{1)}$, by reducing the losses of the collector ${ }^{2}$, by using heat change material which increases the heat transfer performance of $\mathrm{FPC}^{3)}$, by increasing transmittance of the collector ${ }^{4}$.

Kim. et al. ${ }^{5)}$ optimized the active- indirect solar hot water plant at different airports which supply water at $65^{\circ} \mathrm{C}$ and calculated payback periods.

Research works have also been carried out to integrate the collectors with other solar devices to improve the overall efficiency. In the design of evacuated tubes integrated single slope solar still (EISS) a number of evacuated tubes (glass-in-glass type, all facing south) were integrated with the conventional single slope solar still (SS). These tubes were joined at the south wall of SS. Water circulated under natural thermo-siphon effect between SS and these tubes. A thermal model for EISS was developed and analyzed theoretically at different water depths for winter (January 2010) season of New Delhi. The results showed an increased amount of distillate in comparison to SS and founded IESS to be more effective in terms of the amount of distillate over $\mathrm{SS}^{5}$.

Tewari \& Dev ${ }^{6)}$ analyzed the performance of Integrated Photovoltaic Solar Water Heating System with Absorber Coating on Inner Half of the Tube having $53.6^{\circ} \mathrm{C} \& 71^{\circ} \mathrm{C}$ as the maximum hot water temperature for the month of November and April respectively. The overall efficiency of the system found to vary between 27-31\% for the month of April 2015.

From the literature survey, it is clearly depicted that research works are focused toward increasing the output of the systems but less or no work have been done for the climatic conditions of Allahabad, U.P, India. Glazing material other than glass have not been used. However, to increase the transmittance of glazing, different coatings have been used. Most of the studies and research in the field of solar water heating have been done to increase the efficiency of system by modifying collector. Less work towards modification in the storage tank design has been done and separate research works on flat plate collector and evacuated tube collector have been done, no work has been done towards combining these two technology to overcome the disadvantages of both.

In this paper, MSWHS has been modeled and simulated for the climatic condition of Allahabad, which is having the characteristic feature of both FPC and ETC. Major modifications areas are design of the setup and the material used. In conventional systems cylindrical storage tank has been used which has lower surface area (than cuboidal tanks). Opaque storage tank restricts input 
solar radiation and does not allows to watch the internal process going inside the tank. Thus, modifications have been done to overcome these shortcomings of the conventional designs.

Materials used in MSWHS are fiber reinforced plastic and methyl methacrylate which is commonly named as acrylic. Glass fiber reinforced plastic, insulating material has been used which is the strongest and most resistive the deforming forces. Acrylic is also the transparent insulating material with very high transmissivity and abrasion resistance. Theoretical results obtained from modeling of MSWHS have been validated with experimental results.

\section{Design of experimental setup}

MSWHS consists of semi-cylindrical acrylic tubes, metal plate, FRP sheets and a storage tank as shown in Fig. 1. MSWHS is made up of a metal plate (absorber) having sixteen evacuated semi-cylindrical tubes on its top and an insulation of FRP sheet just below the metal plate. Tubes are connected with a cuboidal tank of dimensions $0.86 \times 0.5 \times 0.5 \mathrm{~m}$ mounted at the top. The material used for the tank is a double layer of acrylic sheets except for bottom and north wall which is made up of FRP sheet. The volume of water in tubes and tank are 5.0026L and $194.973 \mathrm{~L}$ respectively to maintain the capacity of 200L of MSWH. The angle of inclination of MSWH is $25^{\circ}$ as per latitude of Allahabad. MSWHS is installed at the Mechanical Engineering Department of Motilal Nehru National Institute of Technology Allahabad, U.P, India as shown in Fig. 2.

Here, tubes and tank are made up of acrylic as it is more flexible and having higher abrasion resistance and corrosion resistance. Acrylic transmits 92\% of visible light and heat insulation is also higher. The acrylic sheet will not shatter as it is having higher impact strength and can be cut easily. Various design parameters of MSWH are shown in Table.1 and can be referred from Tewari and $\operatorname{Dev}^{7,8)}$.

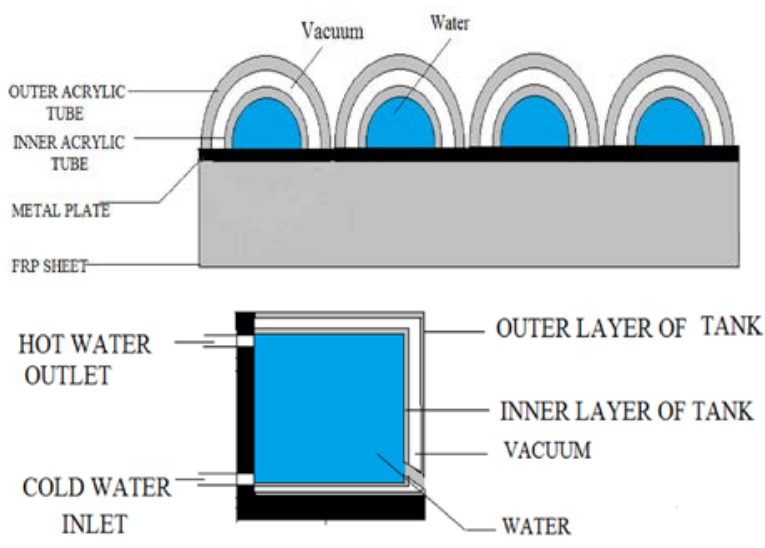

Fig. 1: Cross- sectional view of solar collector and Storage tank.
Table 1. Different Design Parameters of MSWHS

\begin{tabular}{llll}
\hline $\begin{array}{l}\text { Specificati } \\
\text { ons }\end{array}$ & Dimensions & $\begin{array}{l}\text { Specifica } \\
\text { tions }\end{array}$ & Dimensions \\
\hline$\alpha_{\mathrm{p}}$ & 0.95 & $\rho_{\mathrm{w}}$ & $1000 \mathrm{~kg} / \mathrm{m}^{3}$ \\
$\alpha_{\mathrm{FRP}}$ & 0.9 & $\mathrm{~L}$ & $2 \mathrm{~m}$ \\
$\alpha_{\mathrm{w}}$ & 0.6 & $\mathrm{~A}_{\mathrm{P}}$ & $1.6 \mathrm{~m}^{2}$ \\
$\alpha_{\mathrm{acry}}$ & 0.05 & $\mathrm{~K}_{\mathrm{acry}}$ & $0.2 \mathrm{~W} / \mathrm{m} \mathrm{K}$ \\
$\tau_{\mathrm{acry}}$ & 0.92 & $\mathrm{R}_{\mathrm{ii}}$ & $0.01 \mathrm{~m}$ \\
$\tau_{\mathrm{w}}$ & 0.35 & $\mathrm{R}_{\mathrm{i} 0}$ & $0.0125 \mathrm{~m}$ \\
$\mathrm{~h}_{\mathrm{i}}$ & $2.55 \mathrm{~W} / \mathrm{m}^{2} \mathrm{~K}$ & $\mathrm{R}_{\mathrm{oi}}$ & $0.022 \mathrm{~m}$ \\
$\mathrm{~N}_{\mathrm{t}}$ & 16 & $\mathrm{R}_{\mathrm{oo}}$ & $0.025 \mathrm{~m}$ \\
$\dot{\mathrm{m}}$ & $0.02 \mathrm{~kg} / \mathrm{s}$ & $\dot{\mathrm{m}}_{\mathrm{W}}$ & $0.02 \mathrm{~kg} / \mathrm{s}$ \\
$\mathrm{V}_{1 \text { tube }}$ & $0.000314 \mathrm{~m}^{3}$ & $\mathrm{M}_{\mathrm{TW}}$ & $194.973 \mathrm{~kg}$ \\
$\mathrm{~V}_{\mathrm{T}}$ & $200 \mathrm{~L}$ & $\mathrm{~K}_{\mathrm{FRP}}$ & $0.0351 \mathrm{~W} / \mathrm{mK}$ \\
$\mathrm{M}_{\mathrm{tw}}$ & $5.026 \mathrm{~kg}$ & $\mathrm{~h}_{\mathrm{P}}$ & $200 \mathrm{~W} / \mathrm{m}^{2} \mathrm{~K}$ \\
$\mathrm{t}_{\mathrm{FRPi}}$ & $0.0438 \mathrm{~m}$ & $\mathrm{t}_{\mathrm{FRPT}}$ & $0.005 \mathrm{~m}$ \\
$\mathrm{t}_{\mathrm{acryt}}$ & $0.003 \mathrm{~m}$ & $\mathrm{~A}_{\mathrm{E}}$ & $0.243 \mathrm{~m}^{2}$ \\
$\mathrm{~A}_{\mathrm{N}}$ & $0.394 \mathrm{~m}^{2}$ & $\mathrm{~A}_{\mathrm{b}}$ & $0.394 \mathrm{~m}$ \\
$\mathrm{~A}_{\mathrm{W}}$ & $0.243 \mathrm{~m}^{2}$ & Space $\mathrm{b} / \mathrm{W}$ & $0.009 \mathrm{~m}$ \\
$\mathrm{~A}_{\text {top }}$ & $0.394 \mathrm{~m}^{2}$ & Tubes & \\
\hline
\end{tabular}

\section{Working principle}

Working of MSWHS is based on thermosyphon effect. Sun rays falling on collector top gets transmitted by the double layer of the acrylic tube and absorbed by metal absorber plate. This absorber plate then transfers the collected heat to the water flowing inside inner tube of collector and hence water becomes light by gaining heat. Light (heated) water moves up in the tube and cold water from the tank moves downward. Thus, hot water reaches in the storage tank and continue to receive heat in transparent storage tank also as sunlight can pass through acrylic sheets used for making walls and storage tank is designed in such a way that inside heat cannot escape out because of the double layer of the acrylic sheet having a vacuum between them.

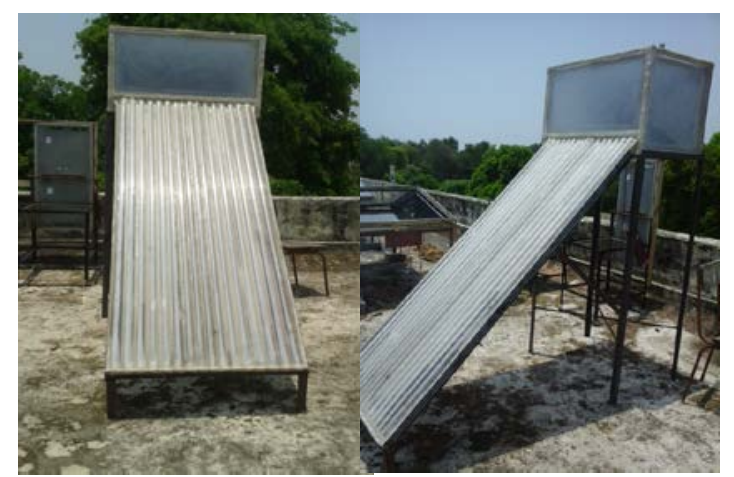

Fig. 2: Photograph of MSWHS 


\section{Thermal modeling}

The energy balance for each component of the MSWH has been carried out with the following assumptions,

a) The setup is completely water and vapor leakage proof.

b) The heat retention capacities of the plate, insulations, FRP, Acrylic are negligible. They do not retain heat with them i.e. MCdT/dt term is negligible.

c) Temperature-dependent heat transfer coefficients have been considered because these values changes with temperature.

d) The system operates in quasi-steady state regime during the day. The thermodynamic properties are not changing with time for an interval of one hour.

e) The temperature of the metal plate and FRP base are considered to be uniform throughout. Variation of temperature along the length is negligible.

\subsection{For Collector}

1. For metal plate:

Heat absorbed by metal plate $=$ heat convected to water + heat conducted to FRP.

$\alpha_{P}\left[\tau_{\text {acry }}^{2} \tau_{w} I_{t}(t)\right] A_{P}=h_{P} A_{P}\left(T_{P}-T_{h w}\right)+\frac{K_{F R P} A_{F R P}\left(T_{P}-T_{F R P}\right)}{t_{F R P i}}$

\section{For FRP:}

Heat conducted to FRP = heat convected to ambient.

$\frac{K_{F R P} A_{F R P}\left(T_{P}-T_{F R P}\right)}{t_{F R P i}}=h_{o} A_{F R P}\left(T_{F R P}-T_{a}\right)$

3. For water in Acrylic tube:

Heat absorbed by water + heat convected to water from metal plate $=$ energy stored by water + heat transfer from hot water in tubes to the water in the tank + heat convected to inner tubes.

$$
\alpha_{w} \tau_{a c r y}^{2} I_{t}(t) A_{i i t} N_{t}+h_{p} A_{P}\left(T_{P}-T_{h w}\right)=M_{t w} C_{w} \frac{d T_{h w}}{d t}
$$$$
+\dot{m}_{w} C_{w}\left(T_{h w}-T_{c w}\right)+h_{\text {kacryi }} A_{i i t} N_{t}\left(T_{h w}-T_{i o}\right)
$$

4. For outer surface of inner tube:

Heat convected to outer surface of inner tube = heat convected from outer surface of inner tube to the inner surface of outer tube.

$$
A_{\text {iit }} N_{t} h_{\text {kacryi }}\left(T_{h w}-T_{i o}\right)=h_{i} A_{\text {iot }} N_{t}\left(T_{i o}-T_{o i}\right)
$$

5. For inner surface of outer tube:
Heat convected from outer surface of inner tube to the inner surface of outer tube = heat conducted to outer surface of outer tube

$$
h_{i} A_{o i t} N_{t}\left(T_{i o}-T_{o i}\right)=h_{\text {kacryo }} A_{o o t} N_{t}\left(T_{o i}-T_{o o}\right)
$$

6. For outer surface of outer tube:

Heat conducted to outer surface of outer tube = heat given to ambient

$$
h_{\text {kacryo }} A_{\text {oot }} N_{t}\left(T_{o i}-T_{o o}\right)=A_{\text {oot }} N_{t} h_{o}\left(T_{o o}-T_{a}\right)
$$

\subsection{For Storage Tank}

1. For water in storage tank :

Rate of heat supplied $=$ rate of heat absorbed + rate of heat rejected

$$
\begin{aligned}
& \alpha_{w}\left\{I_{V}(t) A_{s}+I_{H}(t) A_{\text {top }}\right\} \tau_{\text {acry }}^{2}+\alpha_{w}\left\{I_{E}(t) A_{E}+I_{W}(t) A_{w}\right\} \tau_{\text {accy }}^{2} \\
& +h_{b w} A_{b}\left(T_{b i}-T_{c w}\right)+h_{n w} A_{N}\left(T_{N i}-T_{c w}\right)+\dot{m}_{w} C_{w}\left(T_{h w}-T_{c w}\right)= \\
& M_{T w} C_{w} \frac{d T_{c w}}{d t}+h_{T W} A_{s}\left(T_{c w}-T_{s i i}\right)+h_{T W} A_{\text {top }}\left(T_{c w}-T_{\text {topi }}\right)+ \\
& h_{T W} A_{E}\left(T_{c w}-T_{E i i}\right)+h_{T W} A_{w}\left(T_{c w}-T_{W i i}\right)
\end{aligned}
$$

2. For east wall (inner surface of inner layer):

Heat absorbed from radiation + heat gained from water $=$ heat lost to the outer surface of inner east wall

$\alpha_{\text {acry }}\left\{I_{E}(t) A_{E}\right\} \tau_{\text {acry }}+h_{T W} A_{E}\left(T_{c w}-T_{\text {Eii }}\right)=\frac{K_{\text {acry }} A_{E}\left(T_{\text {Eii }}-T_{\text {Eio }}\right)}{t_{\text {acryt }}}$

3. For east wall (outer surface of inner layer):

Heat conducted to the outer surface of inner east wall $=$ heat convected from outer surface of inner east wall to the inner surface of outer east wall

$$
h_{\text {kacry }} A_{E}\left(T_{\text {Eii }}-T_{\text {Eio }}\right)=h_{i} A_{E}\left(T_{\text {Eio }}-T_{\text {Eoi }}\right)
$$

4. For east wall (inner surface of outer layer):

Heat convected from outer surface of inner east wall to the inner surface of outer east wall $=$ heat conducted from inner surface of outer east wall to the outer surface of outer east wall

$$
h_{i} A_{E}\left(T_{\text {Eio }}-T_{\text {Eoi }}\right)=h_{\text {kacry }} A_{E}\left(T_{\text {Eoi }}-T_{\text {Eoo }}\right)
$$

5. For east wall (outer surface of outer layer):

Heat conducted from inner surface of outer east wall to the outer surface of outer east wall = heat lost to the ambient

$h_{\text {kacry }} A_{E}\left(T_{\text {Eoi }}-T_{\text {Eoo }}\right)=h_{o} A_{E}\left(T_{\text {Eoo }}-T_{a}\right)$

6. For north wall (inner surface):

Heat absorbed from radiation = heat gained by water + heat conduction to the outer surface of north wall 


$$
\alpha_{F R P} I_{V}(t) A_{N} \tau_{a c r y}^{2} \tau_{w}=h_{N w} A_{N}\left(T_{N i}-T_{c w}\right)+\frac{K_{F R P} A_{N}\left(T_{N i}-T_{N o}\right)}{t_{F R P T}}
$$

7. For north wall (outer surface):

Heat conduction from the inner surface to the outer surface of north wall $=$ heat lost to the ambient

$$
h_{k F R P} A_{N}\left(T_{N i}-T_{N o}\right)=h_{o} A_{N}\left(T_{N o}-T_{a}\right)
$$

Similarly, heat balance equation for west wall, south wall, and top wall can be written and the equations (14) and (15) have been derived using equations (1-13). Derivation of Equation (14) and (15) can be referred from Tewari and $\operatorname{Dev}^{7}$.

Temperature of water in tank:

$$
\begin{aligned}
& T_{c w}=\frac{1}{\beta^{+}-\beta^{-}}\left[\overline{g_{1}(t)}\left\{\frac{\left(1-e^{-c^{+} t}\right)}{c^{+}}-\frac{\left(1-e^{-c^{-} t}\right)}{c^{-}}\right\}+\overline{g_{2}(t)}\right. \\
& \left\{\frac{\beta^{+}\left(1-e^{-c^{+} t}\right)}{c^{+}}-\frac{\beta^{-}\left(1-e^{-c^{-} t}\right)}{c^{-}}\right\}+T_{h w o}\left(e^{-c^{+} t}-e^{-c^{-} t}\right)+ \\
& T_{c w o}\left(\beta^{+} e^{-c^{+} t}-\beta^{-} e^{-c^{-} t}\right)
\end{aligned}
$$

Temperature of hot water in tube:

$$
\begin{aligned}
& T_{h w}=\frac{1}{\beta^{+}-\beta^{-}}\left[\overline{g_{1}(t)}\left\{\frac{\beta^{+}\left(1-e^{-c^{-} t}\right)}{c^{-}}-\frac{\beta^{-}\left(1-e^{-c^{+} t}\right)}{c^{+}}\right\}+\right. \\
& \beta^{+} \beta^{-} \overline{g_{2}(t)}\left\{\frac{\left(1-e^{-c^{-} t}\right)}{c^{-}}-\frac{\left(1-e^{-c^{+} t}\right)}{c^{+}}\right\}+T_{h w o}\left(\beta^{+} e^{-c^{-} t}-\beta^{-} e^{-c^{+} t}\right)+ \\
& \beta^{+} \beta^{-} T_{\text {cwo }}\left(e^{-c^{-} t}-e^{-c^{+} t}\right)
\end{aligned}
$$

Thermal Efficiency of MSWHS:

$$
\begin{aligned}
& \eta_{t h}=\frac{\text { Heat output }(Q)}{\text { Input solar radiation }(A . I)} \\
& \eta_{t h}=\frac{m C_{w}\left(T_{c w}-T_{\text {cwo }}\right)}{A_{p} I_{t}(t)+A_{s} I_{s}(t)+A_{\text {Top }} I_{\text {Top }}(t)+A_{E} I_{E}(t)+A_{w} I_{W}(t)}
\end{aligned}
$$

\section{Life cycle assessment and Cost analysis}

Life cycle assessment (LCA) is a measure of the impact of the system on the environment during its whole life cycle. This methodology was developed by Society of Environmental Toxicology and Chemistry ${ }^{11)}$. LCA is determined by embodied energy and energy payback time, energy production factor and life cycle conversion efficiency ${ }^{13)}$. Total capital cost of installation of the system is Rs. 25,915 as shown in Table. 2

\section{Table 2: Capital cost of MSWHS}

\begin{tabular}{ll}
\hline Materials \& Components & Cost (Rs) \\
\hline Acrylic Tubes (Inner tube) & 2,512 \\
Acrylic Tubes (Outer tube) & 5,936 \\
Acrylic Sheet & 1,650 \\
Fiber reinforced Plastic & 7,717 \\
Cast Iron Stand & 1,500 \\
Copper plate & 1,500 \\
Taps & 100 \\
Others (Complete fabrication of & 5,000 \\
material \& labor cost etc.). & \\
Total cost & Rs. 25,915 \\
\hline
\end{tabular}

\section{Results and discussions}

Various parameters of MSWHS have been measured hourly, such as solar intensity at different walls of storage tank and collector, wind speed and ambient temperature using solar power meter (AMPROBE Model SOLAR-100) and anemometer (FLUKE Model BTH401) for eleven hours (07:00-17:00hr) of a day for the climatic condition of Allahabad in the year 2015-16 and theoretical results have been obtained on MATLAB R2014a on the basis of thermal modeling. This theoretical model is developed considering the energy balance of different components of the system which are similar to the thermal models developed for FPC $^{9}$ and ETC ${ }^{5}$.

Hourly variation of water temperature in tubes of the collector from August 2015 to May 2016 for the climatic conditions of Allahabad is shown in Fig. 3. It has been observed that temperature of water increases with solar radiation up to $12: 00 \mathrm{hr}$ and after $12: 00 \mathrm{hr}$ solar radiation decreases but the temperature of water increases because of heat carrying capacity of water. Highest temperature of water in tubes has been obtained for the month of May ( $89{ }^{\circ} \mathrm{C}$ at $16: 00 \mathrm{hr}$ ) followed by April $\left(87.8^{\circ} \mathrm{C}\right.$ at $\left.16: 00 \mathrm{hr}\right)$, September $\left(80.7{ }^{\circ} \mathrm{C}\right.$ at $\left.15: 00 \mathrm{hr}\right)$, August $\left(78.3{ }^{\circ} \mathrm{C}\right.$ at 15:00hr), March $\left(77.8{ }^{\circ} \mathrm{C}\right.$ at $\left.16: 00 \mathrm{hr}\right)$, October $\left(78.2^{\circ} \mathrm{C}\right.$ at $15: 00 \mathrm{hr})$, February $\left(72.3{ }^{\circ} \mathrm{C}\right.$ at $\left.16: 00 \mathrm{hr}\right)$, November (65 ${ }^{\circ} \mathrm{C}$ at $\left.15: 00 \mathrm{hr}\right)$, January $\left(53.4{ }^{\circ} \mathrm{C}\right.$ at $\left.15: 00 \mathrm{hr}\right)$ and lowest temperature has been obtained for the month of December $\left(50.9^{\circ} \mathrm{C}\right.$ at $\left.15: 00 \mathrm{hr}\right)$.

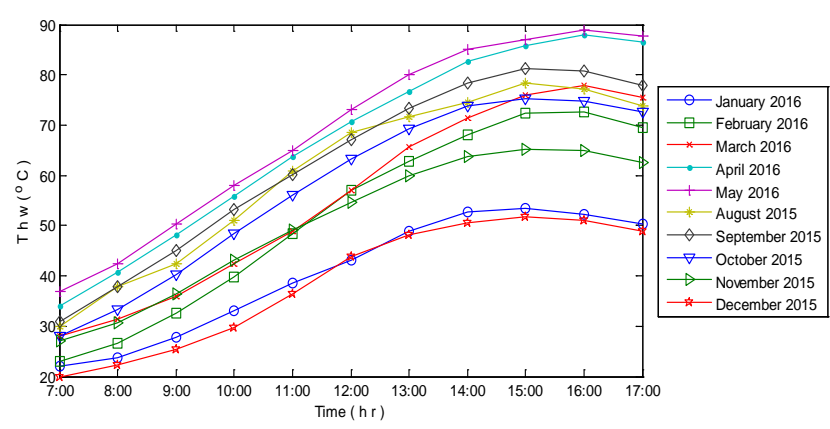

Fig. 3: Hourly variation of water temperature in tubes from August 2015 to May 2016 for the climatic conditions of Allahabad. 
Fig. 4 shows the hourly variation of water temperature in the tank of MSWHS from August 2015 to May 2016 for the climatic conditions of Allahabad. Temperatures in the tank are lower than tubes because of mixing of collector water with the tank water. Highest temperature of water in tank has been obtained for the month of May $\left(85^{\circ} \mathrm{C}\right)$ followed by April $\left(84.6^{\circ} \mathrm{C}\right)$, September $\left(77.8^{\circ} \mathrm{C}\right)$, August $\left(74^{\circ} \mathrm{C}\right)$, March $\left(74.2^{\circ} \mathrm{C}\right)$, October $\left(72.4^{\circ} \mathrm{C}\right)$, February $\left(68.7^{\circ} \mathrm{C}\right)$, November $\left(62.9^{\circ} \mathrm{C}\right)$, January (50.6 ${ }^{\circ} \mathrm{C}$ ) and lowest temperature has been obtained for the month of December $\left(49.1^{\circ} \mathrm{C}\right)$ at $17: 00 \mathrm{hr}$.

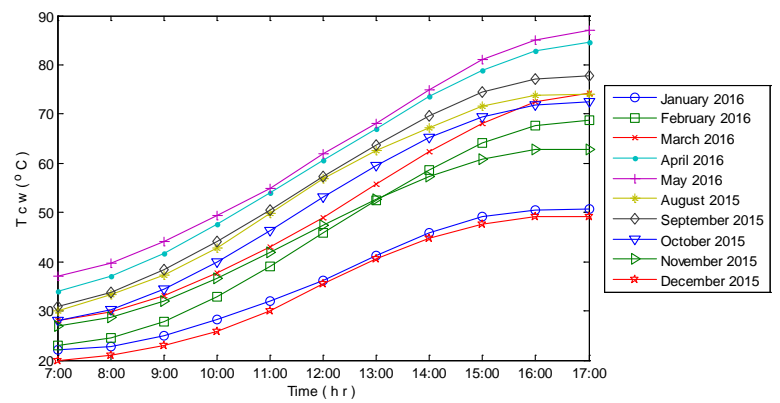

Fig. 4: Hourly variation of water temperature in the tank from August 2015 to May 2016 for the climatic conditions of Allahabad.

Fig. 5 shows the hourly variation of temperatures at different walls of the storage tank and parts of the collector in the month of April 2015 at Allahabad. It has been observed that temperature of all the inner walls of the tank are nearly same because all are in direct contact with the tank water and reaches the maximum temperature of $82.5{ }^{\circ} \mathrm{C}$ in the month of August. In collector, the inner surface of the outer tube has been found to be hottest of all, reaching the maximum temperature of $108.7^{\circ} \mathrm{C}$ at $15: 00 \mathrm{hr}$ and the outer surface reaches the maximum temperature of $95.3{ }^{\circ} \mathrm{C}$. The temperature of the outer surface of the inner tube has been found to be lower than outer tubes temperature and maximum metal plate temperature has been found to be $87.9^{\circ} \mathrm{C}$ at $17: 00 \mathrm{hr}$. Insulation temperature has been found to be the lowest and varying between $32{ }^{\circ} \mathrm{C}$ to 44 ${ }^{\circ} \mathrm{C}$. Since temperatures of the inner surface of the outer tube and the outer surface of the outer tube are in direct relation with the solar intensity, a sudden pick in temperature of these surfaces have been observed at 15:00hr because of a sudden increase in sunshine for a particular day of April month. As solar intensity increases more radiations fall on the outer surface of the tube which increases its temperature and more heat get transmitted through the tubes and hence increases the water temperature. Since water is in direct contact with inner tubes, the temperature of inner tubes surface gets hiked.

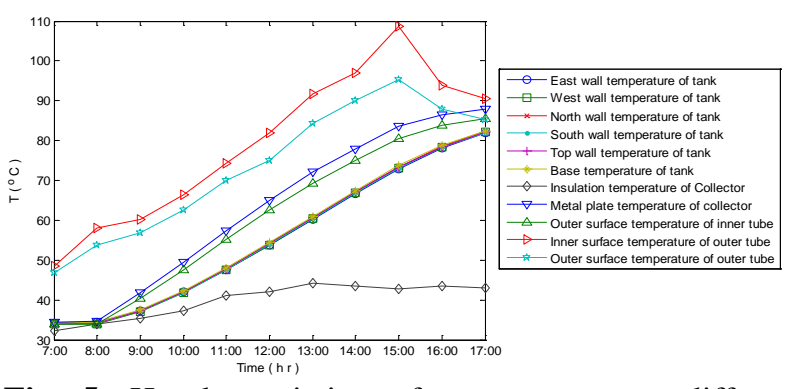

Fig. 5: Hourly variation of temperatures at different walls of tank and parts of the collector in the month of April 2015 at Allahabad.

Fig. 6 shows the hourly variation of water temperature in tubes when absorptivity of the plate is varied from 0.7 to 0.95 . The temperature of water in tubes increases on increasing absorptivity of the plate, as higher absorptivity of metal plate, results in the increased capacity of the plate to capture solar radiation and become hotter and thus, transfers more heat to the water in tubes. For 0.1 increment in absorptivity of metal absorber plate, the temperature of the water has been found to be increased by $1.4{ }^{\circ} \mathrm{C}$. The maximum temperature of hot water has been found to be $74.4^{\circ} \mathrm{C}$, $75.8^{\circ} \mathrm{C}, \quad 77.2^{\circ} \mathrm{C}$ and $77.8^{\circ} \mathrm{C}$ at $16: 00 \mathrm{hr}$ when the absorptivity of the plate is varied from $0.7,0.8,0.9$ and 0.95 . Study of the effect of variation of absorptivity is important since the absorptive capacity of the metal plate of collector is a function of time. Scaling and deposition with time lead to the decrement of absorptivity of the metal plate because of water flowing above it. So this study proves the setup can be used effectively for years, as in worse condition ( 0.7 absorptivity) heating of water is satisfactory but is always advisable to clean the water heater at a proper time interval to maintain the desirable properties of the system. The desirable value of absorptivity is close to 1 but due to availability of material in local market and lack of cleaning results in the compromise in the property of the material.

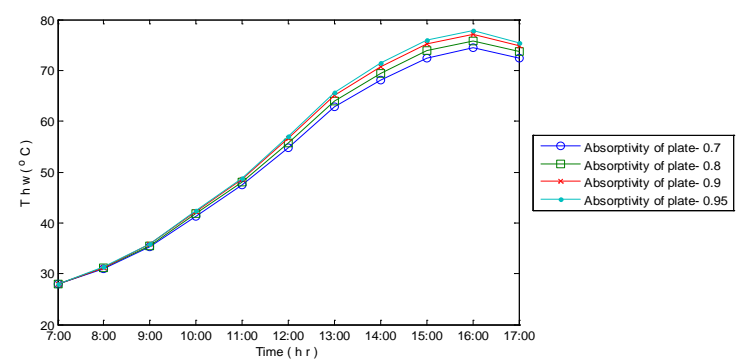

Fig. 6: Hourly variation of water temperature in tubes when absorptivity of the plate is varied from 0.7 to 0.95 .

Fig. 7 shows the hourly variation of water temperature in the storage tank when absorptivity of the plate is varied from 0.7 to 0.95 . Variation of the temperature of inside surface of the outer tube of the collector. Its temperature profile is increasing for all the values of absorptivity and reaches the maximum temperature of $74.2^{\circ} \mathrm{C}, 73.7^{\circ} \mathrm{C}, 72.6^{\circ} \mathrm{C}$ and $71.5^{\circ} \mathrm{C}$ at $17: 00 \mathrm{hr}$ when the 
absorptivity of the plate are $0.95,0.9,0.8$ and 0.7 respectively. An increment of $1^{\circ} \mathrm{C}$ has been found in the tank water temperature on increasing absorptivity by 0.1 .

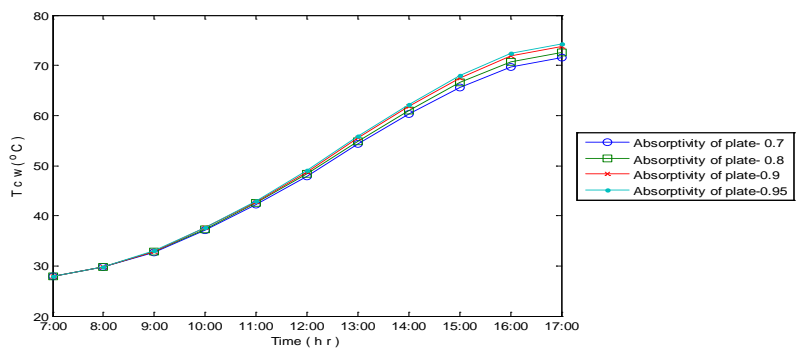

Fig. 7: Hourly variation of water temperature in the tank when absorptivity of the plate is varied from 0.7 to 0.95 .

Fig. 8 shows the hourly variation of water temperature in tubes when the number of tubes is varied from 10 to 25 . With increasing number of tubes, more volume of water will be exposed to the sun in the collector tubes for the same capacity of the heating system and for the same time period. Thus, the higher water temperature will be obtained. Its temperature profile is increasing up to 16:00hr and after 16:00hr again its slope decreases due to no gain in solar radiation in off sunshine hours. Maximum temperatures for 10, 15, 20, 25 number of tubes have been obtained at $69^{\circ} \mathrm{C}, 76.3^{\circ} \mathrm{C}, 83.7^{\circ} \mathrm{C}$, $90.55^{\circ} \mathrm{C}$ respectively at $16: 00 \mathrm{hr}$.

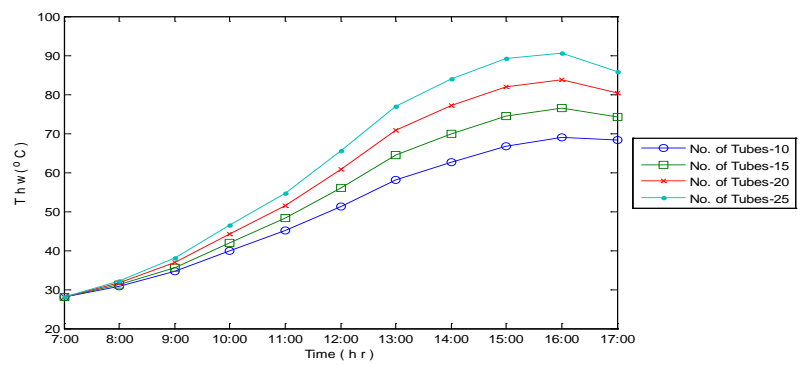

Fig. 8: Hourly variation of water temperature in tubes when the number of tubes is varied from 10 to 25 .

Fig. 9 shows the hourly variation of water temperature in the storage tank when the number of tubes is varied from 10 to 25. Maximum tank water temperatures have been found to be $67.3^{\circ} \mathrm{C}, 73^{\circ} \mathrm{C}, 79.1^{\circ} \mathrm{C}$ and $84.9^{\circ} \mathrm{C}$ at $17: 00 \mathrm{hr}$ for $10,15,20$ and 25 number of tubes respectively.

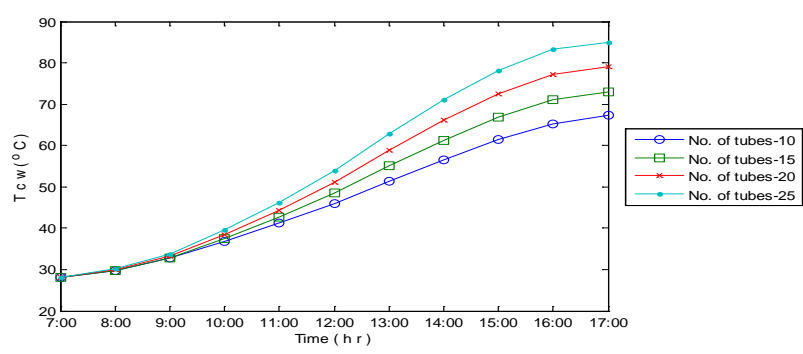

Fig. 9: Hourly variation of water temperature in the tank when the number of tubes is varied from 10 to 25.
Fig. 10 shows the hourly variation of water temperature in tubes when the capacity of the tank is varied from $100 \mathrm{~L}$ to $300 \mathrm{~L}$. A smooth curve is obtained having $30^{\circ} \mathrm{C}$ as minimum temperature and $98.8^{\circ} \mathrm{C}$, $85.5^{\circ} \mathrm{C}, \quad 77.9^{\circ} \mathrm{C}, \quad 72.8^{\circ} \mathrm{C}, \quad 69.2^{\circ} \mathrm{C}$ as maximum temperature at $16: 00 \mathrm{hr}$ when the capacity of the tank had been varied as 100L, 150L, 200L, 250L, 300L respectively. Thus, it can be concluded from the Fig. 10 that on increasing tank capacity water temperature decreases because of the increased volume of water.

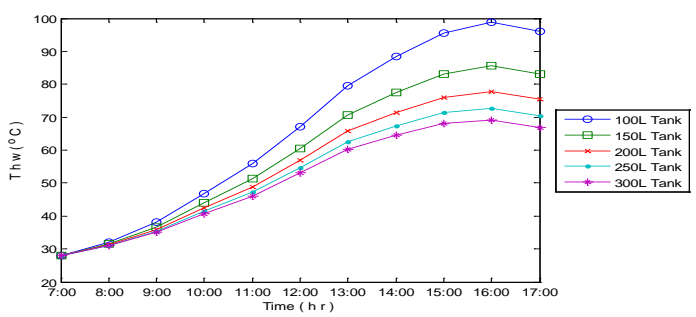

Fig. 10: Hourly variation of water temperature in tubes when the capacity of the tank is varied from 100L to $300 \mathrm{~L}$.

Fig. 11 shows variation of water temperature in storage tank when capacity of tank is varied from 100L to $300 \mathrm{~L} .96^{\circ} \mathrm{C}, 82.3^{\circ} \mathrm{C}, 74.2^{\circ} \mathrm{C}, 68.2^{\circ} \mathrm{C}, 64.9^{\circ} \mathrm{C}$ at $17: 00 \mathrm{hr}$ have been obtained as maximum water temperature in tank for 100L, 150L, 200L, 250L, 300L capacity of tank respectively. Effect of tank capacity, number of tubes and wind speed for the month of March, June, and November have been discussed in 7).

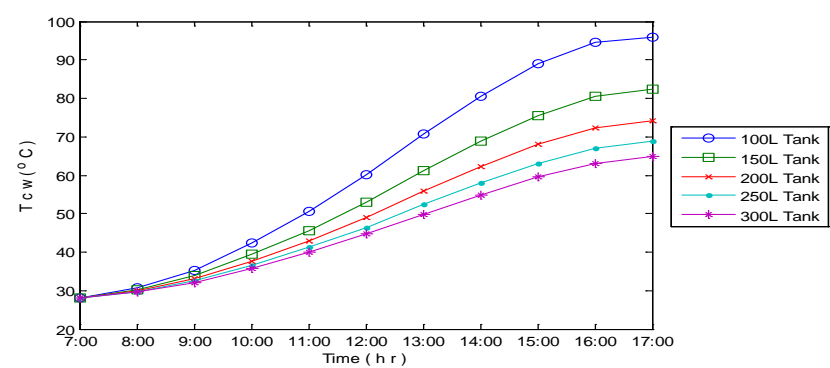

Fig. 11: Hourly variation of water temperature in the tank when the capacity of the tank is varied from $100 \mathrm{~L}$ to $300 \mathrm{~L}$.

Fig. 12 shows the hourly variation of water temperature in tubes with varying mass flow rate for the month of April 2015. Here, three different sets of mass flow rate $(\mathrm{m} 1>\mathrm{m} 2>\mathrm{m} 3)$ have been taken which are given in Table 3 and values of mass flow rate are varying throughout the day in direct relation with incident solar radiation. Calculated collector tubes' water temperature shows that water temperature decreases with increase in mass flow rate. The maximum values of tube water temperature have been found to be $76.3^{\circ} \mathrm{C}, 78.9^{\circ} \mathrm{C}, 82^{\circ} \mathrm{C}$ at $16: 00 \mathrm{hr}$ for $\mathrm{m} 1, \mathrm{~m} 2, \mathrm{~m} 3$ respectively and maximum variation in water temperature has been found to be $5.7^{\circ} \mathrm{C}$ for April. 


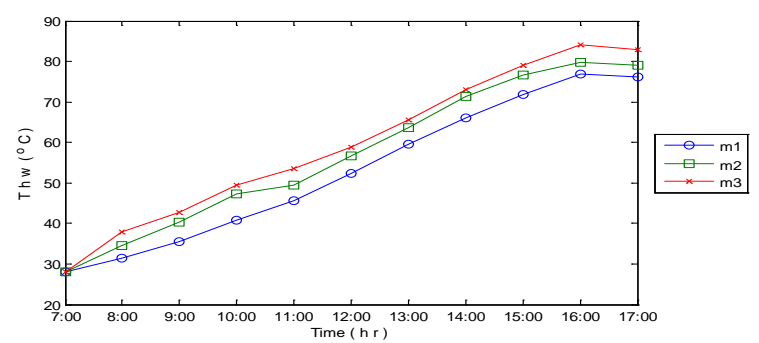

Fig. 12: Hourly variation of water temperature in tubes with varying the mass flow rate

Table 3: Different mass flow rates

\begin{tabular}{cccc}
\hline $\begin{array}{c}\text { Time } \\
(\mathrm{hr})\end{array}$ & $\begin{array}{c}\mathrm{m}_{1} \\
(\mathrm{~kg} / \mathrm{s})\end{array}$ & $\begin{array}{c}\mathrm{m}_{2} \\
(\mathrm{~kg} / \mathrm{s})\end{array}$ & $\begin{array}{c}\mathrm{m}_{3} \\
(\mathrm{~kg} / \mathrm{s})\end{array}$ \\
\hline $7: 00$ & 0.010 & 0.005 & 0.0009 \\
$8: 00$ & 0.017 & 0.007 & 0.001 \\
$9: 00$ & 0.024 & 0.009 & 0.005 \\
$10: 00$ & 0.031 & 0.010 & 0.007 \\
$11: 00$ & 0.049 & 0.022 & 0.010 \\
$12: 00$ & 0.056 & 0.030 & 0.015 \\
$13: 00$ & 0.066 & 0.040 & 0.019 \\
$14: 00$ & 0.060 & 0.030 & 0.016 \\
$15: 00$ & 0.055 & 0.025 & 0.015 \\
$16: 00$ & 0.029 & 0.020 & 0.014 \\
$17: 00$ & 0.018 & 0.006 & 0.001 \\
\hline
\end{tabular}

Fig. 13 shows the hourly variation of water temperature in tubes when the thickness of insulation is varied from $0.0100 \mathrm{~m}$ to $0.0800 \mathrm{~m}$. Effect of insulation thickness on the water temperature of the tube has been found to be negligible between 7:00hr -9:00hr and after 9:00hr its effect has increased, but it can be noticed from the figure that temperature difference is diminishing with increasing thickness and after the thickness of $0.0400 \mathrm{~m}$ difference has become negligible. Thus, optimum thickness for this design has to be near about $0.0400 \mathrm{~m}$ to reduce wastage of material and thus, it has been found to be in good agreement with the value of the thickness of insulation calculated for MSWHS which is $0.0438 \mathrm{~m}$.

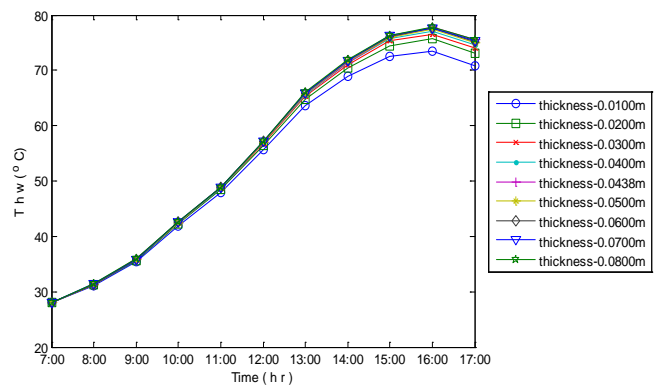

Fig. 13: Hourly variation of water temperature in tubes when the thickness of insulation is varied from $0.0100 \mathrm{~m}$ to $0.0800 \mathrm{~m}$.

Fig. 14 shows the hourly variation of water temperature in tubes when wind speed is varied from $0.0 \mathrm{~m} / \mathrm{s}$ to $3.0 \mathrm{~m} / \mathrm{s}$. As wind velocity increases, convective losses also increases but here, the maximum variation of $1.34^{\circ} \mathrm{C}$ in tube water temperature has been obtained at 17:00hr which shows that the effect of convection losses is almost negligible in MSWHS due to its design. The effect of wind speed or convection losses has been reduced due to vacuum between inner and outer tubes of the collector. Maximum value of tube water temperature has been found to be $78.3^{\circ} \mathrm{C}, 77.7^{\circ} \mathrm{C}, 77.4^{\circ} \mathrm{C}, 77.18^{\circ} \mathrm{C}$ at wind velocity of $0.0 \mathrm{~m} / \mathrm{s}, 1.0 \mathrm{~m} / \mathrm{s}, 2.0 \mathrm{~m} / \mathrm{s}, 3.0 \mathrm{~m} / \mathrm{s}$ at 16:00 hr. Effect of increasing wind speed has been found to be negligible up to $1: 00 \mathrm{hr}$ and after $1: 00 \mathrm{hr}$ change is noticeable.

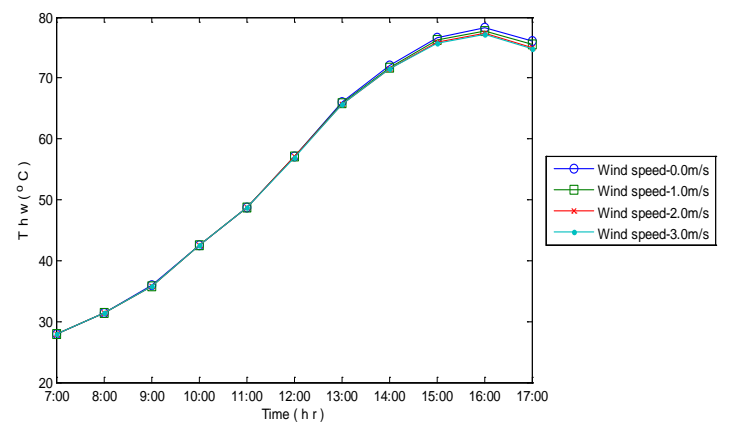

Fig. 14: Hourly variation of water temperature in tubes when wind speed is varied from $0.0 \mathrm{~m} / \mathrm{s}$ to $3.0 \mathrm{~m} / \mathrm{s}$.

Fig. 15 shows the hourly variation of water temperature in the storage tank when wind speed is varied from $0.0 \mathrm{~m} / \mathrm{s}$ to $3.0 \mathrm{~m} / \mathrm{s}$. Here, tank water temperature increases with the minimum at $7: 00 \mathrm{hr}$ to the maximum at $17: 00 \mathrm{hr}$ and it can be observed form this Fig. that maximum cold water temperatures are $74.8^{\circ} \mathrm{C}$, $74.3^{\circ} \mathrm{C}, 74^{\circ} \mathrm{C}, 73.8^{\circ} \mathrm{C}$ at wind velocity of $0.0 \mathrm{~m} / \mathrm{s}, 1.0 \mathrm{~m} / \mathrm{s}$, $2.0 \mathrm{~m} / \mathrm{s}, 3.0 \mathrm{~m} / \mathrm{s}$ at 17:00 hr. Here, the maximum variation of $1.0^{\circ} \mathrm{C}$ has been obtained at $17: 00 \mathrm{hr}$.

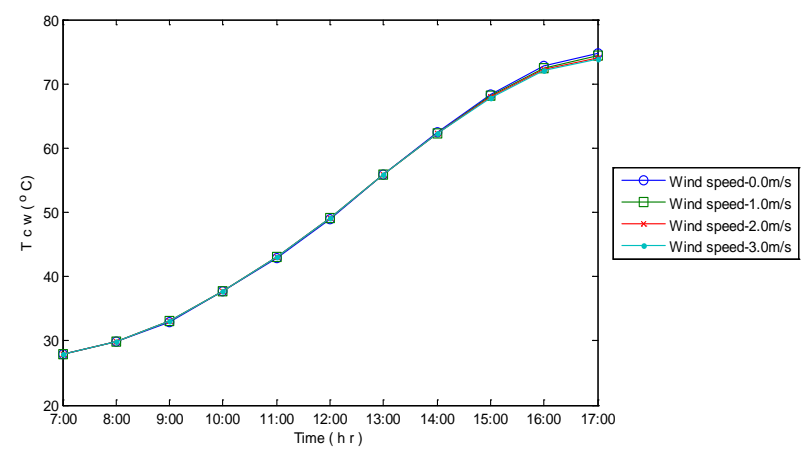

Fig. 15: Hourly variation of water temperature in the tank when wind speed is varied from $0.0 \mathrm{~m} / \mathrm{s}$ to $3.0 \mathrm{~m} / \mathrm{s}$.

Fig. 16 shows the hourly variation of theoretical hot water temperature in collector tubes and storage tank of MSWHS for a particular day of March 2016 and validated against experimental data. Experimental results are plotted against the climatic data collected on 04/03/3016 as shown in Table. 4. Root mean square percent deviation (e) of $8.68 \%$ and $9.44 \%$ respectively for water temperature of collector tubes and storage tank and correlation coefficient (r) of 0.99 have been obtained between theoretical and experimental results. Thus, a 
good agreement has been found to be established between modeling and experimental results. For 04/03/2016 maximum hot water temperature in the tube of the collector and storage tank is found to be $71.07^{\circ} \mathrm{C}$ at $16: 00 \mathrm{hr}$ and $67.26^{\circ} \mathrm{C}$ at $17: 00 \mathrm{hr}$ respectively. Dubey and Tiwari ${ }^{14)}$ had carried out analysis of PV/T flat plate collectors which are connected in series each having collector area of $2 \mathrm{~m}^{2}$ (Partially covered by $\mathrm{PV}$ module) for the climatic condition of Delhi, India and reported maximum water temperature of $69.6^{\circ} \mathrm{C}$ at $15: 00 \mathrm{hr}$ with the mass flow rate of $0.01 \mathrm{~kg} / \mathrm{sec}$ for the month of April when two collectors are connected in series. Thus MSWHS is considered to be very effective which effectively heats the water with the minimum floor area required $\left(1.5 \mathrm{~m}^{2}\right)$ as the space between the tubes of the collector has been removed and there are no losses because of shading effect as the tubes are transparent. The performance of MSWHS in the month of March is satisfactorily matching the job done by the $\mathrm{PV} / \mathrm{T}$ system in the month of April. Weather conditions of Delhi and Allahabad are almost the same.

In today's scenario, people are bounded to live in small houses and apartments with increasing population crowd, they don't have much space for bulky products. The floor area requirement of MSWHS $\left(1.5 \mathrm{~m}^{2}\right)$ is much lower than conventional systems $\left(4.9 \mathrm{~m}^{2}\right)$ for heating the same quantity of water.

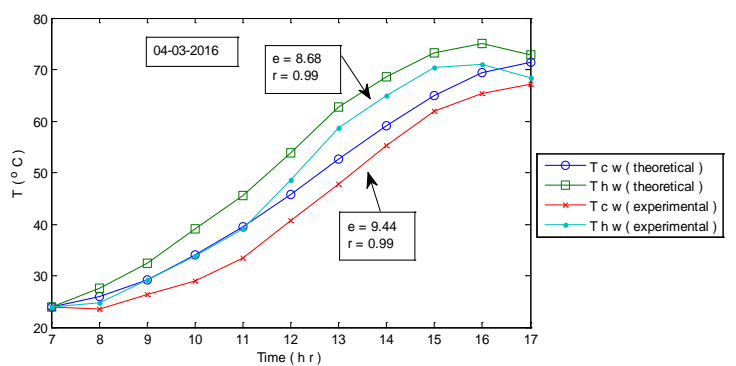

Fig. 16: Hourly variation of hot water temperature in collector tubes and storage tank of MSWHS for a particular day of March.

Fig. 17 shows the variation in efficiency of MSWHS with time for the month of May (summer) and December (winter). The efficiency of the system is found to maintain an average value of $23 \%$ in summer and $20 \%$ in winter between $8: 00 \mathrm{hr}$ to $16: 00 \mathrm{hr}$. The efficiency of the present system is found to be lower than conventional or recently developed flat plate collectors ${ }^{10)}$ because, in MSWH, input solar radiation has been increased due to the transparent storage tank. Here, total input solar radiation is the sum of radiation captured by collector and transparent storage tank. Thus, efficiency has been reduced but the output temperature of the water has been increased. Nada et al. ${ }^{11)}$ have found the maximum efficiency of 0.65 at the mass flow rate of $0.029 \mathrm{~kg} / \mathrm{sec}$ with opaque storage tank in flat plate collector. This efficiency will obviously get reduced if the opaque storage tank is replaced by a transparent tank and will become lower than 65\%. Thus, the efficiency of MSWHS has been found to be satisfactory.

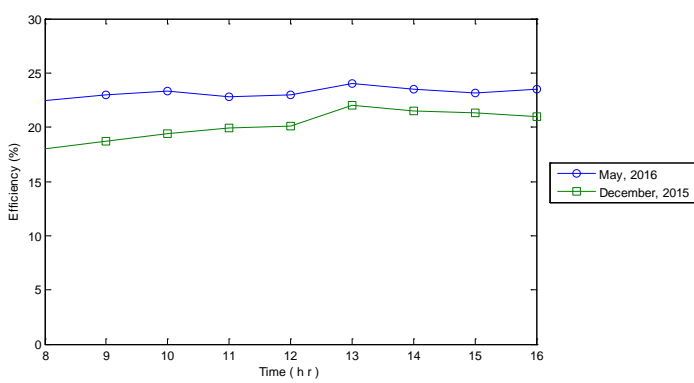

Fig. 17: Hourly variation of efficiency of MSWHS for May 2016 and December 2015.

Table 4. Hourly Observation of MSWHS of March 04 at Allahabad, India

\begin{tabular}{cccccccc}
\hline $\begin{array}{c}\text { Time } \\
(\mathrm{hr})\end{array}$ & $\begin{array}{c}\mathrm{I}_{\mathrm{t}}(\mathrm{t}) \\
\left(\mathrm{W} / \mathrm{m}^{2}\right)\end{array}$ & $\begin{array}{c}\mathrm{I}_{\mathrm{E}}(\mathrm{t}) \\
\left(\mathrm{W} / \mathrm{m}^{2}\right)\end{array}$ & $\begin{array}{c}\mathrm{I}_{\mathrm{W}}(\mathrm{t}) \\
\left(\mathrm{W} / \mathrm{m}^{2}\right)\end{array}$ & $\begin{array}{c}\mathrm{I}_{\mathrm{S}}(\mathrm{t}) \\
\left(\mathrm{W} / \mathrm{m}^{2}\right)\end{array}$ & $\begin{array}{c}\mathrm{I}_{\text {top }}(\mathrm{t}) \\
\left(\mathrm{W} / \mathrm{m}^{2}\right)\end{array}$ & $\begin{array}{c}\mathrm{T}_{\mathrm{a}} \\
\left({ }^{\circ} \mathrm{C}\right)\end{array}$ & $\begin{array}{c}\mathrm{Va} \\
(\mathrm{m} / \mathrm{s})\end{array}$ \\
\hline $07: 00$ & 150 & 620 & 50 & 135 & 230 & 24 & 0.40 \\
$08: 00$ & 200 & 795 & 75 & 180 & 500 & 25 & 1.20 \\
$09: 00$ & 430 & 940 & 150 & 415 & 680 & 29.20 & 0.40 \\
$10: 00$ & 580 & 980 & 180 & 550 & 1110 & 34.60 & 1.20 \\
$11: 00$ & 640 & 586 & 160 & 490 & 1055 & 36.20 & 0.40 \\
$12: 00$ & 1080 & 320 & 280 & 830 & 1110 & 33.70 & 0.90 \\
$13: 00$ & 1098 & 160 & 490 & 820 & 1030 & 33.80 & 1.30 \\
$14: 00$ & 1030 & 130 & 720 & 660 & 960 & 35.30 & 2.80 \\
$15: 00$ & 920 & 110 & 950 & 700 & 820 & 32.60 & 2.00 \\
$16: 00$ & 560 & 127 & 920 & 500 & 600 & 32.10 & 0.40 \\
$17: 00$ & 150 & 105 & 780 & 140 & 250 & 31.20 & 0.40 \\
\hline
\end{tabular}

Table 5 shows the energy matrices of MSWHS by considering annual thermal energy gain $\left(E_{\text {out }}\right)$ which is found to $1203 \mathrm{KWh}$ and embodied energy $\left(\mathrm{E}_{\text {in }}\right)$ of the system is found to be $1658.73 \mathrm{KWh}$ as shown in Table. 6 . $E_{\text {solar }}$ is the annual solar energy received by the system and $\mathrm{n}$ is the life of the setup which is taken as 15 years.

Table 5: Energy production factor, energy payback period and life cycle conversion efficiency of MSWHS considering annual thermal energy.

\begin{tabular}{lll}
\hline $\begin{array}{l}\text { Energy production } \\
\text { factor (EPF) }\end{array}$ & $E P F=\frac{E_{\text {out }}}{E_{\text {in }}}$ & 0.72 \\
$\begin{array}{l}\text { Energy payback } \\
\text { time (EPBT) }\end{array}$ & $E P B T=\frac{1}{E P F}$ & 1.4 years \\
$\begin{array}{l}\text { Life cycle } \\
\begin{array}{l}\text { conversion } \\
\text { efficiency }(\varphi(t))\end{array}\end{array}$ & $\Phi(t)=\frac{\left(E_{\text {out }} \times \mathrm{n}\right)-E_{\text {in }}}{E_{\text {solar }} \times \mathrm{n}}$ & 0.57 \\
\hline
\end{tabular}

Table 6: Embodied energy of components of MSWHS.

\begin{tabular}{ll}
\hline Components & $\begin{array}{l}\text { Embodied energy, kWh } \\
\left(\mathbf{E}_{\text {in }}\right)\end{array}$ \\
\hline Fiber reinforced plastic & 354 \\
Acrylic & 956 \\
Iron stand & 77.72 \\
Plastics & 5.004 \\
Black paint & 6.56 \\
Adhesives & 99.96 \\
G.I fittings & 8.89 \\
Cu sheet & ${ }^{2)}$ \\
Total & 150.6 \\
\hline
\end{tabular}




\section{Conclusions}

Present study proves that the performance of collector improves as vacuum tubes used in the collector reduces the heat loss to the environment, reducing gaps between tubes increases absorber area and the tank of an acrylic sheet having vacuum between them further reduces the loss and increases the solar radiation received. Thus, following conclusions are drawn

6.1. MSWHS can be used beneficially for heating of water.

6.2. Use of acrylic has made the system lighter, less prone to corrosion, easy to transport and install.

6.3. Better utilization of solar radiation by making the transparent tank, which makes the system more suitable for winter conditions where the requirement of hot water is high.

6.4. Integration of some features of FPC and ETC increases the water temperature. The maximum and minimum temperature of water in storage tank has been found in the month of May $\left(85{ }^{\circ} \mathrm{C}\right)$ and December $\left(49.1{ }^{\circ} \mathrm{C}\right)$ respectively. The maximum and minimum temperature of water in tubes of collector has been found in the month of May (89 ${ }^{\circ} \mathrm{C}$ ) and December $\left(50.9{ }^{\circ} \mathrm{C}\right)$ respectively for the year 2015-16 for the climatic condition of Allahabad.

6.5. Parametric study of MSWHS has been performed and it has been found that temperature of water in tubes and tank increases with

6.5.1. increasing absorptivity of absorber plate, number of tubes and

6.5.2. decreasing water capacity of tank and mass flow rate.

6.6. Effect of wind speed has been found to be negligible on the output temperatures of water and hence proofs the design of MSWHS to be free from convective losses, which is an improvement over FPC.

6.8. Energy payback period, energy production factor and life cycle conversion efficiency of MSWHS is found to be 1.4 years, 0.72 and 0.57 .

\section{References}

1) C.D. Ho, T.C. Chen, Renew Energy, 33, 655 (2008).

2) J. Vestlund, M. Ro“nnelid, J.-O. Dalenba“ck, Sol Energy, 83, 896 (2009).

3) Z. Chen, M. Gu, D. Peng, Appl. Therm. Eng., 30, 1967 (2010).

4) N Ehrmann, R. Reineke- Koch, Thin film solids. 520, 4214 (2012).

5) Y. D. Kim, K. Thu, K. C. Ng, EVERGREEN Joint Journal of Novel Carbon Resource Sciences \& Green Asia Strategy, 2, 50 (2015).

6) R. Dev, G.N. Tiwari, Desalin. Water Treat., 41, 204 (2012).
7) K. Tewari, R. Dev, (2016). Proc. National Conference on Advances in Thermal Engineering, Jadavpur University, Kolkata, India (2016).

8) K. Tewari, R. Dev, International Journal of Electrical, Computer, Energetic, Electronic and Communication Engineering, Paris. 10, 73 (2016).

9) R. Dev, K. Tewari, MATTER: International Journal of Science and Technology, 1, 2454 (2017).

10) R. Dev, G.N. Tiwari, DES. , 254, 126 (2010).

11) H.M.S. Nada, S A. El - Ghetany, H H. Hussein, Appl. Therm. Eng., 24, 1959 (2004).

12) G. Tsilingiridis, G. Martinopoulos, N. Kyriakis, Renew Energy, 29, 1277 (2004).

13) S. Dubey, G.N. Tiwari, Open environmental Sciences, 2, 15 (2008).

14) S. Dubey, G.N. Tiwari, Sol Energy, 83, 1485 (2009).

\section{Nomenclature}

$\mathrm{T}_{\text {FRP }}$ - Temperature of FRP sheet $\left({ }^{\circ} \mathrm{C}\right)$

$\mathrm{T}_{\mathrm{p}}$ - Temperature of absorber plate $\left({ }^{\circ} \mathrm{C}\right)$

$\mathrm{T}_{\text {oо }}$ - Temperature of outer surface of outer tube of collector $\left({ }^{\circ} \mathrm{C}\right)$

$\mathrm{T}_{\mathrm{oi}}$ - Temperature of inner surface of outer tube $\left({ }^{\circ} \mathrm{C}\right)$

$\mathrm{T}_{\mathrm{io}}$ - Temperature of outer surface of inner tube $\left({ }^{\circ} \mathrm{C}\right)$

$\mathrm{T}_{\text {Eoo }}$ - Temperature of outer surface of outer layer of east wall $\left({ }^{\circ} \mathrm{C}\right)$

$\mathrm{T}_{\text {Eoi }}$ - Temperature of inner surface of outer layer of east wall $\left({ }^{\circ} \mathrm{C}\right)$

$\mathrm{T}_{\text {Eio }}$ - Temperature of outer surface of inner layer of east wall $\left({ }^{\circ} \mathrm{C}\right)$

$\mathrm{T}_{\text {sii }}$ - Temperature of inner surface of inner layer of south wall $\left({ }^{\circ} \mathrm{C}\right)$

$\mathrm{T}_{\text {wii }}$ - Temperature of inner surface of inner layer of west wall $\left({ }^{\circ} \mathrm{C}\right)$

$\mathrm{T}_{\text {topii }}$ - Temperature of inner surface of inner layer of top wall $\left({ }^{\circ} \mathrm{C}\right)$

$\mathrm{T}_{\text {No }}$ - Outer surface temperature of north wall $\left({ }^{\circ} \mathrm{C}\right)$

$\mathrm{T}_{\mathrm{bi}}$ - Inner surface temperature of bottom wall of tank $\left({ }^{\circ} \mathrm{C}\right)$

$\mathrm{T}_{\mathrm{Ni}}$ - Inner surface temperature of north wall $\left({ }^{\circ} \mathrm{C}\right)$

$\mathrm{T}_{\mathrm{cw}}$ - Temperature of cold water in tank $\left({ }^{\circ} \mathrm{C}\right)$

$\mathrm{T}_{\mathrm{hw}}$ - Temperature of hot water in in tube $\left({ }^{\circ} \mathrm{C}\right)$

$\mathrm{T}_{\text {hwo }}$ - Initial hot water temperature $\left({ }^{\circ} \mathrm{C}\right)$

$\mathrm{T}_{\text {cwo }}$ - Initial cold water temperature $\left({ }^{\circ} \mathrm{C}\right)$

$\alpha_{p}$ - Absorptivity of absorber plate

$\alpha_{\text {FRP }}$ - Absorptivity of FRP.

$\alpha_{\mathrm{w}}$ - Absorptivity of water.

$\alpha_{\text {acry }}$ - Absorptivity of acrylic tubes.

$\mathrm{V}_{\mathrm{a}}$ - Velocity of air $(\mathrm{m} / \mathrm{s})$

$\mathrm{T}_{\mathrm{a}}$ - Ambient temperature $\left({ }^{\circ} \mathrm{C}\right)$

Nt- No of tubes

L- Length of tubes (m)

$\rho$ - Density of water $\left(\mathrm{kg} / \mathrm{m}^{3}\right)$

$\tau_{\mathrm{w}}$ - Transmitivity of water

$\tau_{\text {acry }}$ - Transmitivity of tubes. 
$A_{p}$ - Area of metallic plate $\left(\mathrm{m}^{2}\right)$

$\mathrm{A}_{\text {iit }}$ - Inside area of inner tube $\left(\mathrm{m}^{2}\right)$

$\mathrm{A}_{\text {iot }}$ - Outside area of inner tube $\left(\mathrm{m}^{2}\right)$

$\mathrm{A}_{\text {oit }}$ - Inside area of outer tube $\left(\mathrm{m}^{2}\right)$

$\mathrm{A}_{\text {oot }}$ - Outside area of outer tube $\left(\mathrm{m}^{2}\right)$

$\mathrm{R}_{\mathrm{ii}}$ - Inside radius of inner tube (m)

$\mathrm{R}_{\mathrm{io}}$ - Outside radius of inner tube (m)

$\mathrm{R}_{\mathrm{oi}}$ - Inside radius of outer tube (m)

$\mathrm{R}_{\mathrm{oo}}$ - Outside radius of outer tube (m)

$A_{s}$ - Area of south wall of storage tank $\left(\mathrm{m}^{2}\right)$

$A_{\text {top }}$ - Area of top wall of storage tank $\left(\mathrm{m}^{2}\right)$

$A_{E}$ - Area of east wall of storage tank $\left(\mathrm{m}^{2}\right)$

$A_{w}$ - Area of west wall of storage tank $\left(\mathrm{m}^{2}\right)$

$A_{N}$ - Area of north wall of storage tank $\left(\mathrm{m}^{2}\right)$

$A_{b}$ - Area of bottom wall of storage tank $\left(\mathrm{m}^{2}\right)$

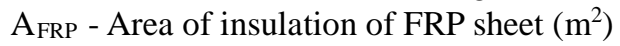

$\mathrm{It}(\mathrm{t})$ - Solar radiation on collector $\left(\mathrm{W} / \mathrm{m}^{2}\right)$

Is $(\mathrm{t})$ - Solar radiation on south wall of tank $\left(\mathrm{W} / \mathrm{m}^{2}\right)$

$\mathrm{I}_{\mathrm{E}}(\mathrm{t})$ - Solar radiation on east wall of tank $\left(\mathrm{W} / \mathrm{m}^{2}\right)$

$I_{w}(t)$ - Solar radiation on west wall of tank $\left(\mathrm{W} / \mathrm{m}^{2}\right)$

$\mathrm{I}_{\text {top }}(\mathrm{t})$ - Solar radiation on top wall of tank $\left(\mathrm{W} / \mathrm{m}^{2}\right)$

$\mathrm{C}_{\mathrm{w}}$ - Specific heat of water $(\mathrm{J} / \mathrm{kg}-\mathrm{k})$

$t_{\mathrm{FRPi}}$ - Thickness of insulation (m)

$\mathrm{t}_{\mathrm{FRPt}}$ - Thickness of wall (m)

$t_{a c r y}$ - Thickness of acrylic wall of tank (m)

$\mathrm{K}_{\text {FRP }}$ - Thermal conductivity of FRP (W/m-K)

$\mathrm{K}_{\mathrm{acry}}$ - Thermal conductivity of acrylic $(\mathrm{W} / \mathrm{m}-\mathrm{K})$

$\mathrm{M}_{\mathrm{tw}}$ - Total mass of water in all tube $(\mathrm{kg})$

$\mathrm{M}_{\mathrm{Tw}}$ - Remaining water mass in tank $(\mathrm{kg})$

$\mathrm{m}$ - Mass flow rate of water $(\mathrm{kg} / \mathrm{sec})$

$\mathrm{h}_{\mathrm{o}}$ - Radiative- convective heat transfer coefficient between outer acrylic tube and ambient as well as between walls of tank and ambient $\left(\mathrm{W} / \mathrm{m}^{2} \mathrm{~K}\right)$

$h_{i}$ - Radiative heat transfer coefficient between outer surface of inner tube and inner surface of outer tube as well as between south, east, west and top outer surface of inner layer and inner surface of outer layer $\left(\mathrm{W} / \mathrm{m}^{2} \mathrm{~K}\right)$

hp - Convective heat transfer coefficient between absorber plate and water in tube $\left(\mathrm{W} / \mathrm{m}^{2} \mathrm{~K}\right)$

hTw - Convective heat transfer coefficient between water in tank and south, east, west and top inner surface of inner layer $\left(\mathrm{W} / \mathrm{m}^{2} \mathrm{~K}\right)$

hnw - Convective heat transfer coefficient between water in tank and inner surface of north wall $\left(\mathrm{W} / \mathrm{m}^{2} \mathrm{~K}\right)$

hbw - Convective heat transfer coefficient between water in tank and inner surface of bottom surface $\left(\mathrm{W} / \mathrm{m}^{2} \mathrm{~K}\right)$

$\mathrm{N}$ - Number of observations

$\mathrm{X}$ - Theoretical values

Y- Experimental values

\section{Appendix A: various intermediate expressions for thermal modeling of MSWH}

$$
\begin{aligned}
& T_{F R P}=\frac{\left[T_{P}+T_{a} \frac{h_{o} t_{F R P}}{K_{F R P}}\right]}{\left[1+\frac{h_{o} t_{F R P}}{K_{F R P}}\right]} \\
& T_{E i i}=\frac{\alpha_{a c r y} I_{E}(t) \tau_{a c r y}+h_{T W} T_{c w}+h_{c} T_{a}}{U_{1}} \\
& T_{W i i}=\frac{\alpha_{a c r y} I_{w}(t) \tau_{a c r y}+h_{T W} T_{c w}+h_{c} T_{a}}{U_{1}} \\
& T_{\text {topii }}=\frac{\alpha_{\text {acry }} I_{H}(t) \tau_{\text {acry }}+h_{T W} T_{c w}+h_{c} T_{a}}{U_{1}} \\
& a_{1}+\beta a_{2}=c \\
& A_{2}=\frac{A_{i i t}}{A_{\text {oit }}} \\
& V_{1}=h_{i}+h_{\text {kacryi }} A_{2}-\frac{A_{1} h_{i}^{2}}{U} \\
& a_{1}=\frac{\dot{m}_{w} C_{w}+A_{i t i} N_{t} h_{\text {kacryi }}+h_{p} A_{p}}{M_{t w} C_{w}}-\frac{h_{p}^{2} A_{p}}{V_{o} M_{t w} C_{w}}-\frac{A_{i i t} N_{t} h_{\text {kacryi }}^{2}}{V_{1} M_{t w} C_{w}} \\
& b_{1}=\left(-\frac{\dot{m}_{w}}{M_{t w}}\right) \\
& g_{1}(t)=\frac{\alpha_{w} \tau_{a c y y}^{2} I_{t}(t) A_{i i t} N_{t}}{M_{t w} C_{w}}+\frac{h_{P} A_{P} \alpha_{P} \tau_{a c r y}^{2} \tau_{w} I_{t}(t)}{U_{o} M_{t w} C_{w}}+ \\
& \frac{h_{P} A_{P} h_{F R P \_O} T_{a}}{U_{o} M_{t w} C_{w}}+\frac{A_{i i t} N_{t} h_{\text {kacryi }} V_{o} T_{a}}{V_{1} M_{t w} C_{w}} \\
& T_{\text {Eoo }}=\frac{h_{\text {kacry }} T_{E o i}+h_{o} T_{a}}{h_{\text {kacry }}+h_{o}} \\
& g_{2}(t)=\frac{\alpha_{w} \tau_{\text {acry }}^{2}}{M_{T w} C_{w}}\left(I_{V}(t) A_{S}+I_{H}(t) A_{\text {top }}+I_{E}(t) A_{E}+I_{W}(t) A_{W}\right) \\
& +\frac{\tau_{a c r y}^{2} \alpha_{F R P} \tau_{w}}{M_{T w} C_{w}}\left(\frac{I_{H}(t) h_{b w} A_{b}}{U_{2 b}}+\frac{I_{V}(t) h_{N w} A_{N}}{U_{2 N}}\right)+\frac{h_{T W} \tau_{\text {acry }} \alpha_{a c r y}}{M_{T w} C_{w} U_{1}} \\
& \left(I_{V}(t) A_{S}+I_{H}(t) A_{\text {top }}+I_{E}(t) A_{E}+I_{W}(t) A_{w}\right) \\
& +\frac{T_{a} h_{\text {kERP_O }}}{M_{T w} C_{w}}\left(\frac{h_{b w} A_{b}}{U_{2 b}}+\frac{h_{N w} A_{N}}{U_{2 N}}\right)+\frac{h_{T W} h_{c} T_{a}}{M_{T w} C_{w} U_{1}}\left(A_{S}+A_{E}+A_{w}+A_{\text {top }}\right) \\
& h_{\text {ikacry }}=h_{i} h_{\text {kacry }} \\
& h_{\text {okacry }}=h_{o} h_{\text {kacry }} \\
& h_{A}=h_{\text {kacry }} h_{\text {ikacry }}+h_{\text {kacry }} h_{i o}+h_{\text {kacry }} h_{\text {okacry }} \\
& h_{B}=h_{i} h_{\text {okacry }}
\end{aligned}
$$




$$
\begin{aligned}
& h_{i o}=h_{i} h_{o} \\
& U_{1}=\frac{h_{T W} h_{A}+h_{T W} h_{B}+h_{B} h_{\text {kacry }}}{h_{A}+h_{B}} \\
& h_{c}=\left(\frac{h_{\text {kacry }} h_{B}}{h_{A}+h_{B}}\right) \\
& h_{\text {kFRP_o }}=\frac{h_{k F R P} h_{o}}{h_{o}+h_{k F R P}} \\
& h_{\text {kFRP }}=\frac{K_{\text {FRP }}}{t_{\text {FRPt }}} \\
& U_{2 N}=\frac{h_{N w} h_{o}+h_{N w} h_{k F R P}+h_{o} h_{k F R P}}{h_{o}+h_{k F R P}} \\
& U_{2 b}=\frac{h_{b w} h_{o}+h_{b w} h_{k F R P}+h_{o} h_{k F R P}}{h_{o}+h_{k F R P}} \\
& a_{2}=\left(-\frac{\dot{m}_{w}}{M_{T w}}\right) \\
& A_{1}=\frac{A_{o i t}}{A_{\text {oot }}} \\
& h_{\text {kacryo-o }}=\frac{h_{\text {kacryo }} h_{o}}{h_{o}+h_{\text {kacryo }}} \\
& h_{F R P-O}=\frac{K_{F R P} h_{o}}{K_{F R P}+h_{o} t_{F R P}} \\
& T_{P}=\frac{\alpha_{P} \tau_{a c r y}^{2} \tau_{w} I_{t}(t)+h_{P} T_{h w}+h_{F R P-O} T_{a}}{U_{O}} \\
& T_{N o}=\frac{T_{N i} h_{k F R P}+T_{a} h_{o}}{h_{k F R P}+h_{o}} \\
& T_{i o}=\frac{T_{a} V_{o}+A_{2} h_{\text {kacryi }} T_{h w}}{V_{1}} \\
& T_{o o}=\frac{h_{o} T_{a}+h_{\text {kacryo }} T_{o i}}{h_{o}+h_{\text {kacryo }}} \\
& T_{\text {Eio }}=\frac{T_{E i i} h_{A}+T_{a} h_{B}}{h_{A}+h_{B}} \\
& T_{o i}=\frac{T_{a} h_{\text {kacryo } o}+A_{1} T_{i o} h_{i}}{U} \\
& T_{\text {Sii }}=\frac{\alpha_{\text {acry }} I_{V}(t) \tau_{a c r y}+h_{T W} T_{c w}+h_{c} T_{a}}{U_{1}} \\
& r=\frac{N \Sigma X Y-(\Sigma X)(\Sigma Y)}{\sqrt{N \Sigma X^{2}-(\Sigma X)^{2}} \sqrt{N \Sigma Y^{2}-(\Sigma Y)^{2}}} \\
& e=\sqrt{\frac{\sum\left(e_{i}\right)^{2}}{N}} \\
& e_{i}=\left[\frac{X-Y}{X}\right] 100
\end{aligned}
$$

